\title{
Onshore transport of settlement-stage Nassau grouper Epinephelus striatus and other fishes in Exuma Sound, Bahamas
}

\author{
Jonathan M. Shenker ${ }^{1,2}$, Elizabeth D. Maddox ${ }^{2}$, Edward Wishinski ${ }^{2}$, \\ Alexander Pearl ${ }^{2}$, Simon R. Thorrold ${ }^{2}$, Ned Smith ${ }^{3}$ \\ ${ }^{1}$ Florida Institute of Technology, Department of Biological Sciences, 150 West University Boulevard, Melbourne, \\ Florida 32901, USA \\ ${ }^{2}$ Caribbean Marine Research Center, c/o Florida Institute of Technology, Department of Biological Sciences, 150 West \\ University Boulevard, Melbourne, Florida 32901, USA \\ ${ }^{3}$ Harbor Branch Oceanographic Institution, 5600 Old Dixie Highway, Fort Pierce, Florida 34946, USA
}

\begin{abstract}
The movement of settlement-stage fishes from the pelagic environment of Exuma Sound, Bahamas, to shallow nursery areas on the Great Bahamas Bank was monitored for $75 \mathrm{~d}$ during winter 1990-1991. Fishes were collected with channel nets suspended in tidal passes between islands on the edge of Exuma Sound. Large-scale movement of fishes through the channels was restricted to flood tides that occurred during dark, moonless times of the night; very little movement was observed during the day, on ebb tides, or on moonlit nights. Many of the dominant taxa (e.g. leptocephali, Bothidae) recruited on dark nights throughout the study period, with peak onshore movement on nights when winds and currents had strong cross-shelf components of motion. Other taxa had very short, discrete recruitment pulses associated with specific environmental events; $86 \%$ of the total annual recruitment of Nassau grouper Epinephelus striatus occurred during a single $4 \mathrm{~d}$ storm that triggered extensive cross-shelf movement of water, while another $10 \%$ of the recruitment occurred during a second storm event. This reliance on unpredictable storm events to drive local recruitment suggests that short-term variability in wind-driven currents is a possible mechanism behind the significant interannual variability of many fish species.
\end{abstract}

\section{INTRODUCTION}

Recruitment is one of the dominant processes that regulates population sizes and community structure in many marine ecosystems. Understanding the biotic and abiotic parameters that affect recruitment is currently a major focus of marine ecologists and resource managers seeking to explain and predict population fluctuations and shifts in community structure. Research on population regulation and recruitment of fishes in coral reef ecosystems has focused on several primary processes: (1) feeding, survival and growth of pelagic larvae; (2) settlement to demersal or benthic habitats; and (3) post-settlement survival and growth (see recent reviews by Doherty 1991, Jones 1991, Leis 1991, and Victor 1991). Each of these processes may constitute a 'bottleneck' in recruitment that limits population size; different processes may act as bottlenecks on different species or in different years.
Studies on recruitment of fishes from pelagic to nursery habitats in coral reef environments have been conducted by censusing and examining newly-settled fishes on coral heads or artificial reefs (Victor 1982, 1983, 1984, 1986b, McFarland et al. 1985, Doherty 1987. Robertson et al. 1988), and by using light traps to assess the abundance of larvae immediately prior to settlement (Milicich 1988, Thorrold \& Milicich 1990. Milicich et al. 1992). Although many of these studies indicated that settlement can be an episodic or rare event, the biotic and abiotic factors controlling settlement have not been determined. Clearly, evaluation of the roles of larval behavior and the physical oceanographic environment in affecting settlement of tropical marine fishes are critical steps in understanding highly dynamic recruitment processes (Sale 1990).

In this paper, we present the results of a $75 \mathrm{~d}$ long survey of fishes captured during their movement from 
the larval pelagic habitat of Exuma Sound, Bahamas, to the shallow water nursery environment on the Great Bahama Bank. Onshore movement and associated environmental conditions were monitored continuously from mid-December 1990 through February 1991. Our analysis focuses on the most abundant taxa that were collected, including the Nassau grouper Epinephelus striatus. E. striatus is a major predator in coral reef systems, supports an important fishery in many parts of the Caribbean, and is highly susceptible to overfishing (Bannerot et al. 1987, Colin 1992). An understanding of the recruitment dynamics of these fish will help in development of appropriate fishery management strategies, and in evaluating the effects of variable levels of recruitment on reef fish community structure.

\section{MATERIALS AND METHODS}

Study site. Field work was conducted from the Caribbean Marine Research Center, on Lee Stocking Island (LSI) on the western edge of Exuma Sound, Bahamas (Fig. 1). Exuma Sound is a deep (2000 m), semienclosed basin, approximately $200 \mathrm{~km}$ long and $50 \mathrm{~km}$ wide. It is bounded by nearly vertical walls rising to within $30 \mathrm{~m}$ of the surface, and a 1 to $5 \mathrm{~km}$ wide shelf that supports coral reef habitats. Several large islands comprise the eastern boundary of the Sound. The western side of Exuma Sound is bordered by a chain of several hundred small islands separating the Sound from the broad, shallow Great Bahama Bank. The Bank contains seagrass, sand and coral head environments, and averages 3 to $4 \mathrm{~m}$ in depth.

Channel net collections. Fishes moving between the pelagic environment and the shallow Great Bahama Bank were collected with channel nets suspended in tidal passes between LSI and adjacent islands (Fig. 1). Channel nets remained in the water continuously at Stns 1, 2 and 3 from 16 December 1990 through 28 February 1991, and at Stn 4 from 1 January through 28 February 1991

Samples were collected from 2 channel nets maintained on separate moorings at each of the stations. All nets could swing freely with tidal changes. Samples were typically removed from the nets shortly after dawn and again before dusk. This regime produced collections containing fishes captured during both flood and ebb tides. To examine transport on discrete flood and ebb tides, nets at Stns 1 to 3 were sampled at each slack tide during 5 nights in January and February.

At each station, one net (mouth area $=2 \mathrm{~m}$ wide $x$ $1 \mathrm{~m}$ deep) was suspended at the surface, and fished the 0 to $1 \mathrm{~m}$ depth stratum. Buoys were used to suspend the second net (mouth area $=2 \mathrm{~m}$ wide $\times 2 \mathrm{~m}$ deep) below the surface to fish the 2 to $4 \mathrm{~m}$ depth stratum in channels that ranged from 6 to $9 \mathrm{~m}$ deep. All nets were constructed of $2 \mathrm{~mm}$ mesh, with a $3 \mathrm{~m}$ long PVC pipe attached along the upper side of the net to prevent the net from collapsing during slack tide and fouling on the mooring line (Fig. 2). A float attached just in front of the heavy PVC cod-end bucket supported the end of the net; during times of slow water movement, the cod-end bucket would sink and pinch off the net, preventing captured fishes from escaping. Each net was equipped with a General Oceanics Model 2030R2 flowmeter with a low speed rotor.

Immediately after collection, all samples were returned to the laboratory, sorted to remove debris (typically Sargassum, algae, and seagrass blades), and preserved in 5 to $10 \%$ formalin in seawater. After 48 to $96 \mathrm{~h}$,

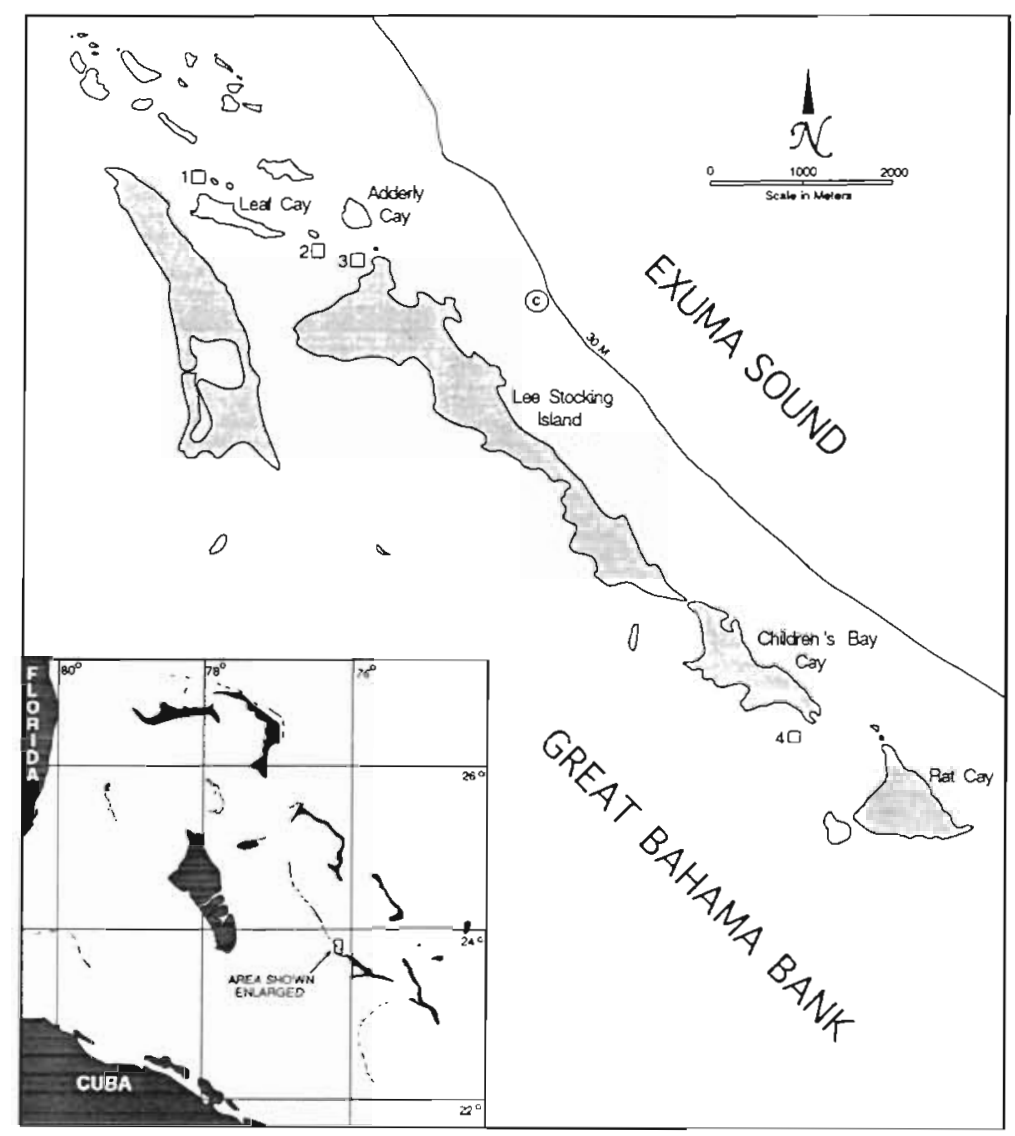

Fig. 1. Location of Lee Stocking Island, Bahamas, and sampling stations. (c): location of current meters 

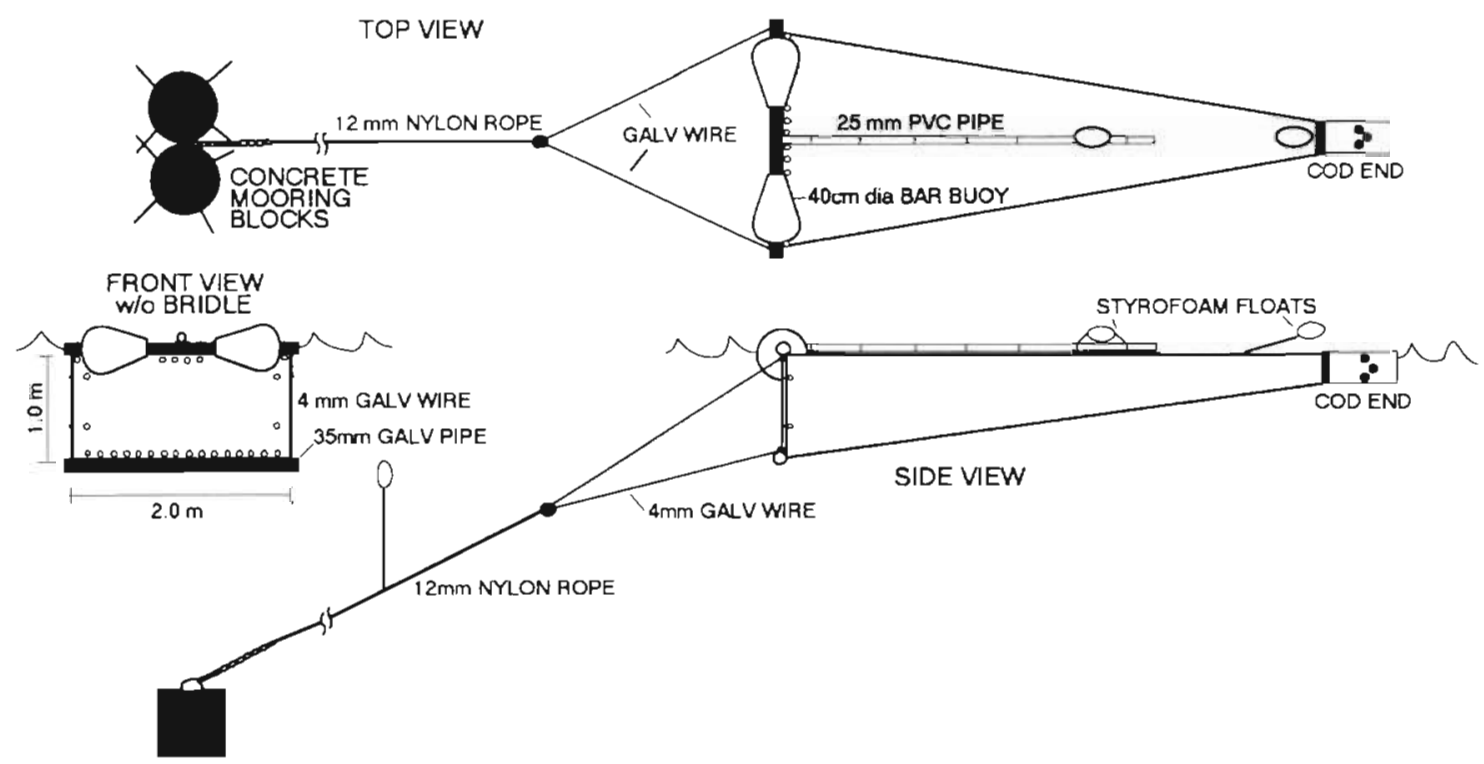

Fig. 2. Schematic diagram of the surface channel net. The subsurface net $(2 \times 2 \mathrm{~m}$ mouth area $)$ was suspended from buoys to fish at a depth of 2 to $4 \mathrm{~m}$ below the surface

samples were switched to $50 \%$ isopropyl alcohol. All fishes were subsequently removed, identified to at least family level whenever possible, and enumerated.

Environmental data. Measurements of wind and current direction and velocity were used to evaluate the role of meteorological and oceanographic conditions on cross-shelf transport of fishes. Wind data were collected hourly throughout the entire study period by a Campbell Scientific weather station at the LSI airstrip, and daily averages were computed from hourly readings. For use in data analysis, the daily wind vectors were broken down into cross-shelf and along-shelf components of motion.

Nearshore currents were measured beginning on 20 January 1991 with General Oceanics Mark II current meters suspended at depths of 10 and $20 \mathrm{~m}$ on a mooring near the shelf edge at a depth of $30 \mathrm{~m}$ (Fig. 1). Hourly measurements of current direction and velocity were averaged for each $24 \mathrm{~h}$ period. Each mean daily current vector was broken into cross-shelf and alongshelf components of motion.

Initial examination of the catch data suggested that moonlight strongly affected cross-shelf movement. For each night of the study, we therefore calculated the total number of hours during which flood tide occurred in complete darkness (i.e. prior to moon rise, or after moon set). In addition, an index of lunar intensity was calculated as the hours of moon-illuminated night flood tide multiplied by the lunar fraction illumination. The lunar fraction illumination was measured as the percentage of the lunar disk visible to earth, with 1.0 representing a full moon and 0.0 representing a new moon.
Data analysis. Total numbers of fish in each taxon in each sample were used to examine differences between catch rates in day and night samples, surface and sub-surface nets, and among stations. Total numbers were also used to evaluate day-to-day variation. Fish densities were not determined for most catches, because our standard sampling procedure produced samples encompassing both ebb and flood tides. However, quantitative estimates of fish densities and transport through the channels on discrete ebb and flood tides were obtained on 5 occasions when samples were collected near dusk, at each tide change through the night, and again at dawn. Filtered water volumes were then used to calculate fish densities for those samples.

Paired $t$-tests were used to statistically test for differences in day and night catch rates for each of the abundant ( $\geq 100$ fish) taxa. Because night samples typically spanned $14 \mathrm{~h}$, and day samples covered $10 \mathrm{~h}$, catch data were standardized to fish caught per hour prior to analysis. Similar standardization and paired $t$-test procedures were used to compare simultaneous catches of fishes in the surface nets $\left(2 \mathrm{~m}^{2}\right.$ mouth area) and subsurface nets ( $4 \mathrm{~m}^{2}$ mouth area).

\section{RESULTS}

\section{Environmental conditions}

Weather patterns varied throughout the study period, ranging from relatively calm conditions to passage of strong frontal systems (Fig. 3). Northerly 
winds from mid-December through early January had a strong onshore component and a general southeasterly component of motion. Mid- to late January was characterized by light and variable winds. Two strong cold fronts passed over Exuma Sound in early and midFebruary. These storms were characterized by northeasterly to northwesterly winds averaging 5 to $7 \mathrm{~m} \mathrm{~s}^{-1}$, and had significant onshore and southeasterly alongshelf components of motion. The storms were followed by a return to light and variable winds.

The winds associated with the February cold fronts apparently triggered shifts in the near-surface currents that were detected by the current meter moored at $10 \mathrm{~m}$ near the shelf edge (Fig. 3). During the calm
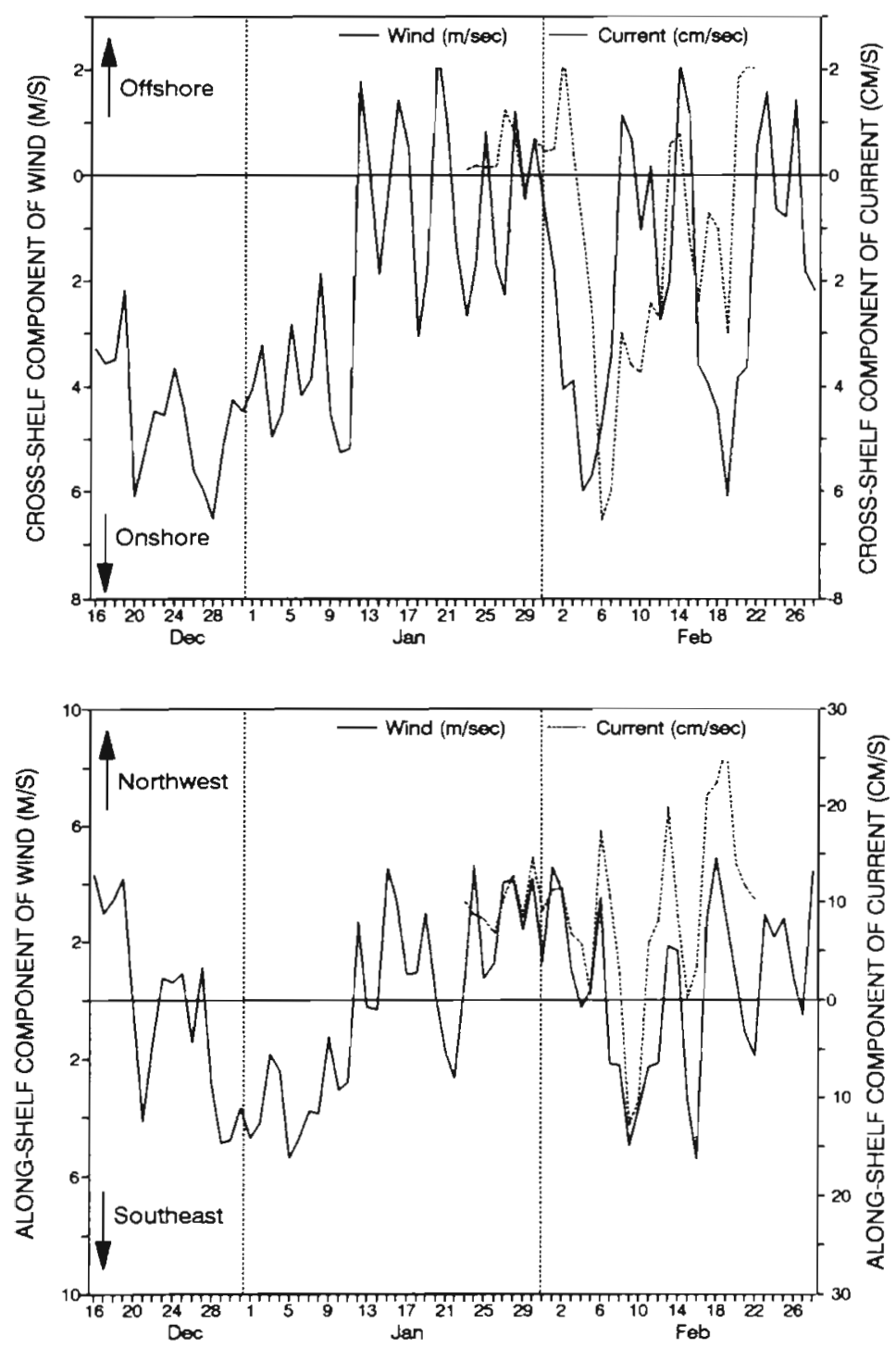

Fig. 3. Cross-shelf and along-shelf components of winds and currents during the study period period preceding the first front, the current at $10 \mathrm{~m}$ flowed along the shelf toward the northwest. As winds associated with the first front began to blow strongly from the northeast, the current started flowing across the shelf, and finally reversed direction toward the southeast. The current resumed northwesterly flow along the shelf between fronts. The second front again induced the current at $10 \mathrm{~m}$ to flow across the shelf, although the cross-shelf flow was not as strong as during the early February front. Currents at a depth of $20 \mathrm{~m}$ generally flowed along the coast to the northwest throughout this period, and did not dramatically respond to passage of weather systems (data not shown).

The hours of flood tide under dark night conditions (Fig. 4) varied with the lunar cycle, reaching peak values of 6 to $6.5 \mathrm{~h}$ per night during new moon periods, and decreasing to 0 during the full moon nights. The lunar intensity index peaked during the full moons (Fig. 4), and decreased very rapidly over the following few nights as the time of moon rise became later and later, and more of the evening flood tide occurred prior to rise of the bright waning moon.

A comparison of water volumes filtered by surface and subsurface nets during the 5 nights when discrete tides were sampled indicated that flood tide flow at the surface layer was slightly higher than 2 to $4 \mathrm{~m}$ below the surface. The surface nets filtered approximately $10 \%$ more water per $\mathrm{m}^{2}$ net mouth area than did the subsurface nets.

\section{Taxon abundance}

A total of 10376 fishes, representing more than 60 taxa, were collected in 1155 channel net samples (Table 1). Nearly all of these fishes were in the larval, settlement, or pelagic juvenile stages of development (Leis 1991). More than $26 \%$ of the fishes were leptocephalus larvae of the orders Anguilliformes and Elopiformes (Drass \& Shenker 1992). The next most abundant taxon collected was the family Serranidae, including 1302 settlement-stage Epinephelus striatus. More than 100 specimens of each of 15 other taxa were collected.

Each of these abundant taxa exhibited dramatic temporal and spatial variations in their movements through the tidal channels. Significant differences in catches were noted 
between day and night collections, between surface and subsurface nets, among the 4 stations, between flood and ebb tides, and from night to night throughout the $75 \mathrm{~d}$ study.

\section{Diel, depth and station patterns in abundance}

Significantly greater numbers of each abundant $(n \geq$ 100) taxon were collected at night than during the day (paired $t$-tests, $\mathrm{p}<0.001$ ), with more than $92 \%$ of the total number of fishes being taken between sunset and sunrise (Table 1). Most of the abundant taxa taken at night were collected primarily in the surface layer of the channels (Table 2). Paired $t$-tests, using data standardized for the different sizes of nets and the slightly higher flow rate of the surface layer, showed that the 3 most abundant groups (leptocephali, Serranidae and Bothidae) and 6 other taxa were significantly more numerous in surface samples at night $(\mathrm{p}<0.001)$. The Clupeidae and Ophididae were the only families with a significant preference for the mid-depth layer $(p<0.001$ and 0.019 , respectively), while the Acanthuridae, Apogonidae and Labridae were evenly distributed through both depth layers. Fishes also moved through different parts of the channels at different rates. For example, the total number of fishes, leptocephali and settling-stage Epinephelus striatus were far more abundant at Stn 2 than at the other 3 stations (Fig. 5). Flow rates at this station were generally greater than those observed at the other stations.

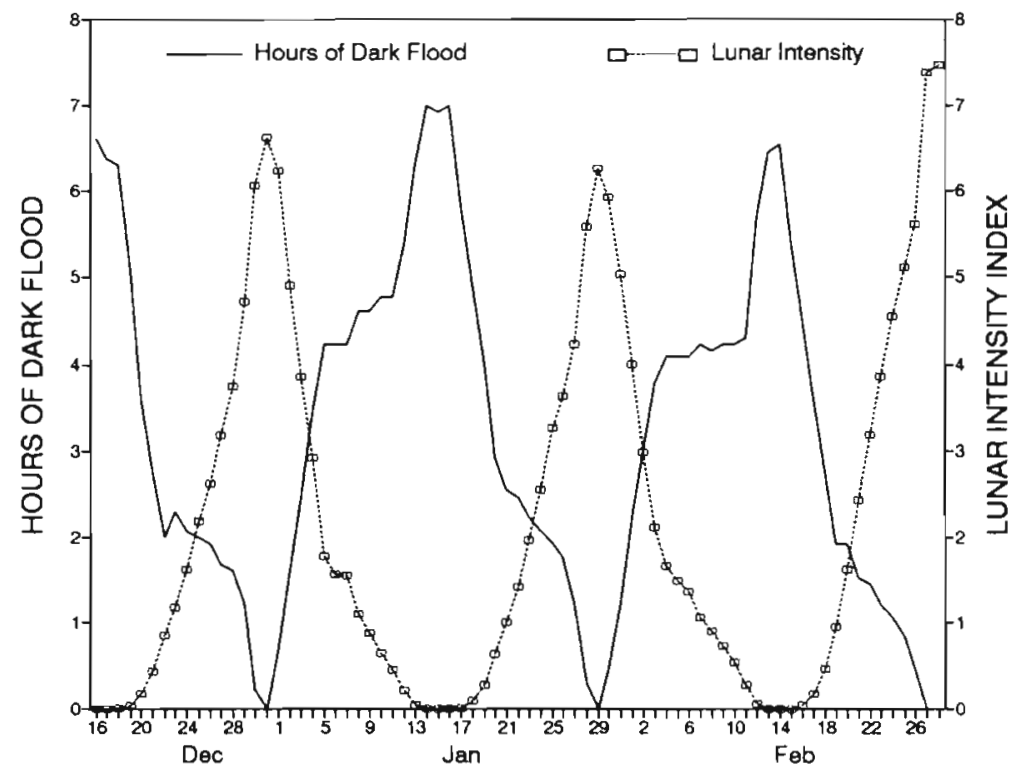

Fig. 4. Hours of dark (moonless) flood tide and lunar intensity index during flood tide each night during the study period

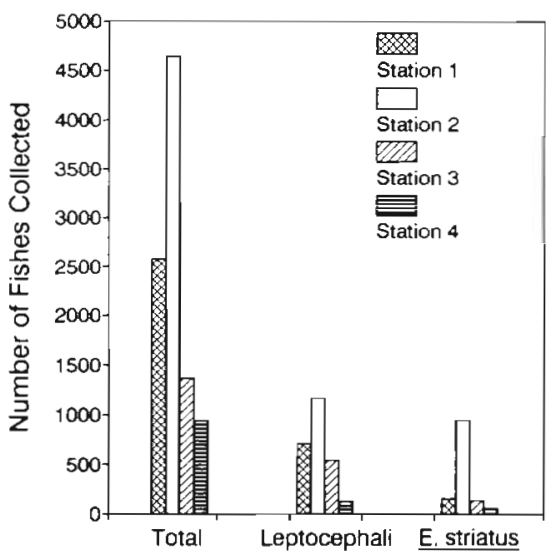

Fig. 5. Total fishes, leptocephali and settlement-stage Epinephelus striatus collected at night at each station throughout the study

\section{Flood and ebb tidal movement of fishes}

Almost all of the fishes collected during sampling of discrete ebb and flood tides at Stns 1 to 3 were captured on the flood tides (Fig. 6a to e), indicating virtually unidirectional movement onto the Great Bahama Bank. Each of these nights had a different combination of lunar phase and wind condition, and the numbers of fishes and taxa collected varied widely. Mean densities among the 3 stations during the strong recruitment episodes on 6-7 and 11-12 February exceeded 4.5 fishes $1000 \mathrm{~m}^{-3}$, compared to levels below 0.85 fishes $1000 \mathrm{~m}^{-3}$ in the January samples. Most of the onshore movement was concentrated in the surface layer during these major recruitment pulses.

\section{Temporal variation in recruitment}

As indicated above, the numbers of fishes moving through the channels varied widely over the duration of the study. Four basic patterns were found among the abundant taxa, indicating that recruitment strategies varied widely among the types of fishes present during the winter:

(1) The most common recruitment pattern was exemplified by those taxa collected throughout the $75 \mathrm{~d}$ study, but which had the great majority of crossshelf movement occurring under a certain set of environmental conditions: nights when the flood tides occurred primarily under moonless conditions, and when there were strong onshore components of 
Table 1. Total number of fishes collected by the channel nets throughout the 2.5 mo long survey, and the percentage of the specimens that were taken in night samples

\begin{tabular}{|c|c|c|c|c|c|}
\hline Taxon & $\begin{array}{c}\text { No. of } \\
\text { specimens }\end{array}$ & $\begin{array}{l}\% \text { taken } \\
\text { at night }\end{array}$ & Taxon & $\begin{array}{c}\text { No. of } \\
\text { specimens }\end{array}$ & $\begin{array}{l}\% \text { taken } \\
\text { at night }\end{array}$ \\
\hline Leptocephalus & 2753 & 93.3 & Callionymidae & 22 & 90.9 \\
\hline Serranidae & 1563 & 97.1 & Holocentridae & 21 & 85.7 \\
\hline Bothidae & 1025 & 90.8 & Ogocephalidae & 21 & 95.2 \\
\hline Clupeidae & 663 & 95.6 & Pomacanthidae & 19 & 78.9 \\
\hline Tetraodontidae & 519 & 86.5 & Sphyraenidae & 19 & 73.7 \\
\hline Acanthuricae & 416 & 90.6 & Opistognathidae & 16 & 93.3 \\
\hline Blennioidei & 353 & 95.8 & Belonidae/Exocoetidae & 15 & 93.3 \\
\hline Gobiesocidae & 349 & 88.8 & Kyphosidae & 13 & 92.3 \\
\hline Balistidae & 327 & 79.1 & Exocoetidae & 11 & 63.7 \\
\hline Ophidiidae & 313 & 95.8 & Coryphaenidae & 7 & 57.1 \\
\hline Gobiidae & 282 & 95.7 & Aulostomidae & 4 & 100.0 \\
\hline Apogonidae & 262 & 93.8 & Microdesmidae & 4 & 75.0 \\
\hline Labridae & 223 & 91.2 & Priacanthidae & 4 & 75.0 \\
\hline Antennariidae & 161 & 84.4 & Soleidae & 4 & 100.0 \\
\hline Unidentified & 109 & 77.4 & Trachipteridae & 3 & 100.0 \\
\hline Scaridae & 103 & 88.7 & Lobotidae & 3 & 100.0 \\
\hline Scorpaenidae & 101 & 94.5 & Mullidae & 3 & 100.0 \\
\hline Carangidae & 100 & 75.0 & Istiophoridae & 2 & 100.0 \\
\hline Atherinidae & 90 & 93.3 & Mugilidae & 2 & 100.0 \\
\hline Syngnathidae & 84 & 93.8 & Atheriniformes & 1 & 100.0 \\
\hline Synodontidae & 82 & 98.8 & Clupeiformes & 1 & 100.0 \\
\hline Elver & 62 & 98.3 & Engraulidae & 1 & 100.0 \\
\hline Trichiuridae & 55 & 80.0 & Fistulariidae & 1 & 100.0 \\
\hline Scombridae & 45 & 95.6 & Bramidae & 1 & 100.0 \\
\hline Ostraciidae & 35 & 88.6 & Lutjanidae & 1 & 100.0 \\
\hline Sparidae & 32 & 87.5 & Malacanthidae & 1 & 100.0 \\
\hline Stomiiformes & 24 & 95.8 & & & \\
\hline Gerreidae & 23 & 100.0 & & & \\
\hline Myctophidae & 22 & 95.5 & Total & 10376 & 92.3 \\
\hline
\end{tabular}

motion of the wind and surface currents. Two of the most abundant taxa (leptocephali and Bothidae) fit this pattern closely (Fig. 7a). Recruitment peaks were characterized by relatively high levels of onshore transport during the period of northerly winds early in the study, except when the full moon greatly reduced the number of hours of flood tide occurring in the dark. Low recruitment occurred during mid- to late January, which was characterized by light and variable winds, and the transition from new to full moon. Dramatic pulses of onshore movement coincided with the passage of 2 storm fronts in February that promoted extensive cross-shelf water movement (Fig. 3). Most of each night's flood tide during these pulses occurred prior to moonrise.

Very similar patterns with recruitment peaks in midDecember, early January, and during the storms in February were seen for the Ophididae and Labridae. Other taxa (Gobiesocidae, Blennioidei, Balistidae, and Apogonidae) had recruitment pulses during at least 2 of these periods. Low numbers of Tetraodontidae were taken continuously during December and January, with peaks during the periods of northeasterly winds in February.
(2) In contrast to the taxa which recruited throughout the study, other taxa were transported onshore during very short, discrete pulses. These groups included settlement-stage Epinephelus striatus, which was the second most abundant taxon taken, larval Epinephelinae and larval Acanthuridae.

The first discrete pulse observed was comprised of small epinepheline larvae (6 to $10 \mathrm{~mm}$ standard length. SL) collected on 7 to 9 January (Fig. 7b). This pulse consisted primarily of Epinephelus striatus larvae, along with some larval E. fulvus (C. B. Greenwood \& J. M. Shenker unpubl.). Later in the month, larval epinephelines were taken offshore of LSI by an ichthyoplankton survey (Greenwood \& Shenker unpubl.). The few epinepheline larvae collected in February consisted of larval E. fulvus, E. guttatus and E. adscensionis

Although larval Epinephelus striatus apparently moved away from the coast in mid- to late January, the cohort reappeared as settlement-stage individuals in a dramatic pulse of recruitment that lasted only 4 nights in early February (Fig. 7b). This pulse coincided precisely with the arrival of a strong storm front that in- 

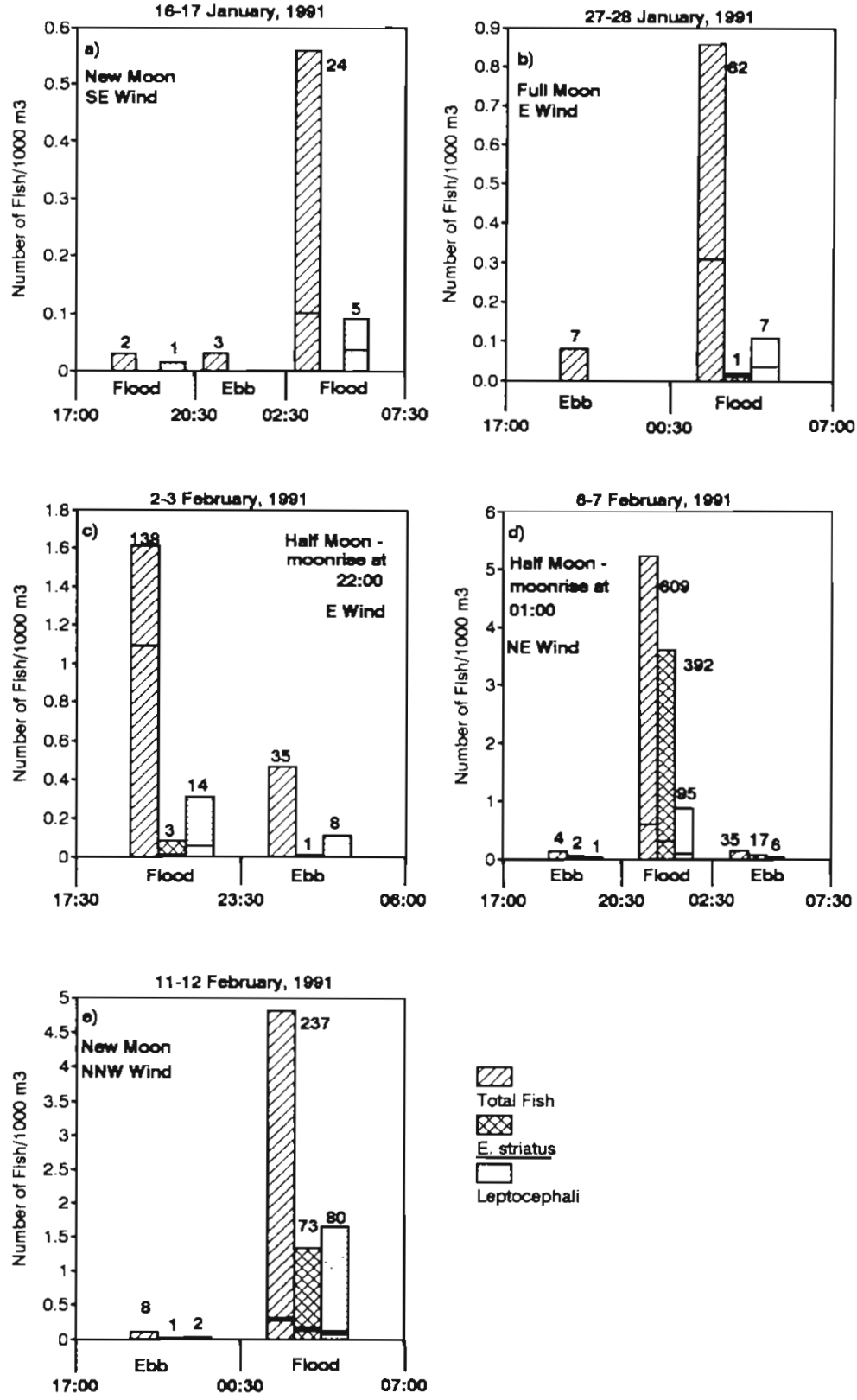

Fig. 6. Mean densities of total fishes, settlement-stage Epinephelus striatus and leptocephali collected in 3 sets of channel nets on flood and ebb tides on 5 nights. Numbers above each bar indicate total numbers of fish taken. Horizontal lines in each bar indicate mean densities of each taxon in subsurface nets, while height of entire bar indicates mean densities in surface nets

duced significant onshore currents (Fig. 3). A total of 1049 Nassau groupers were collected during these nights, and 74 were taken in day samples; $86.3 \%$ of the entire annual recruitment occurred during this one storm event. A smaller pulse occurred from 10 to 13 February, contributing another $9.9 \%$ of the total annual recruitment. This second pulse also occurred during a period of onshore winds and currents. Only a few isolated settlement-stage $E$. striatus individuals, never more than 4 per night, were taken at any other time. Fish in the major recruitment pulses averaged $23.4 \mathrm{~mm} \mathrm{SL}$ (range 18 to $30 \mathrm{~mm}$ ).

Nearly $87 \%$ of all larval Acanthuridae collected during the study period were transported onshore in a single pulse in mid-February: 275 specimens were taken on the night of 17 February, with 36 and 16 specimens being collected the following 2 nights. These larvae ranged from 4 to $8 \mathrm{~mm}$ in length, and were considered too young to settle and recruit (Chlebowski 1991). The pulse coincided precisely with the second storm in February that drove onshore current flow (Fig. 3).

(3) A group of other taxa taken throughout the study occurred generally in low numbers ( $<5$ to 10 fish) each night, with only a few slightly larger peaks observed during the study. However, during the full moon periods, catches of all taxa dropped off to zero. The Antennariidae and Gobiidae (Fig. 7c) exemplify this group, which includes the Scorpaenidae, Scaridae, and Carangidae.

(4) Capture of only a single family, Clupeidae (Fig. 7d) occurred during full moon periods. Most clupeids were collected around the full moon in late December, with a smaller peak in abundance the following month

\section{Conditions for recruitment}

Regardless of the temporal patterns of recruitment for most abundant taxa, onshore transport was typically restricted to nights characterized by certain environmental conditions. The proportions of the total catch of each taxon were determined for nights with different lunar intensity levels, and for nights with different amounts of flood tide occurring in moonless conditions (Fig. 8a, b). Statistical evaluation (G-test; Sokal \& Rohlf 1981) indicated that catches of all taxa but Balistidae and Clupeidae were significantly higher during nights with 4 to $6 \mathrm{~h}$ of dark flood tide than during nights with $<4 \mathrm{~h}$ of dark flood tide (Fig. 8a). Similarly, high lunar intensity index values $(>2)$ resulted in low levels of onshore transport (Fig. $8 b)$. The Clupeidae was the only taxon that was 

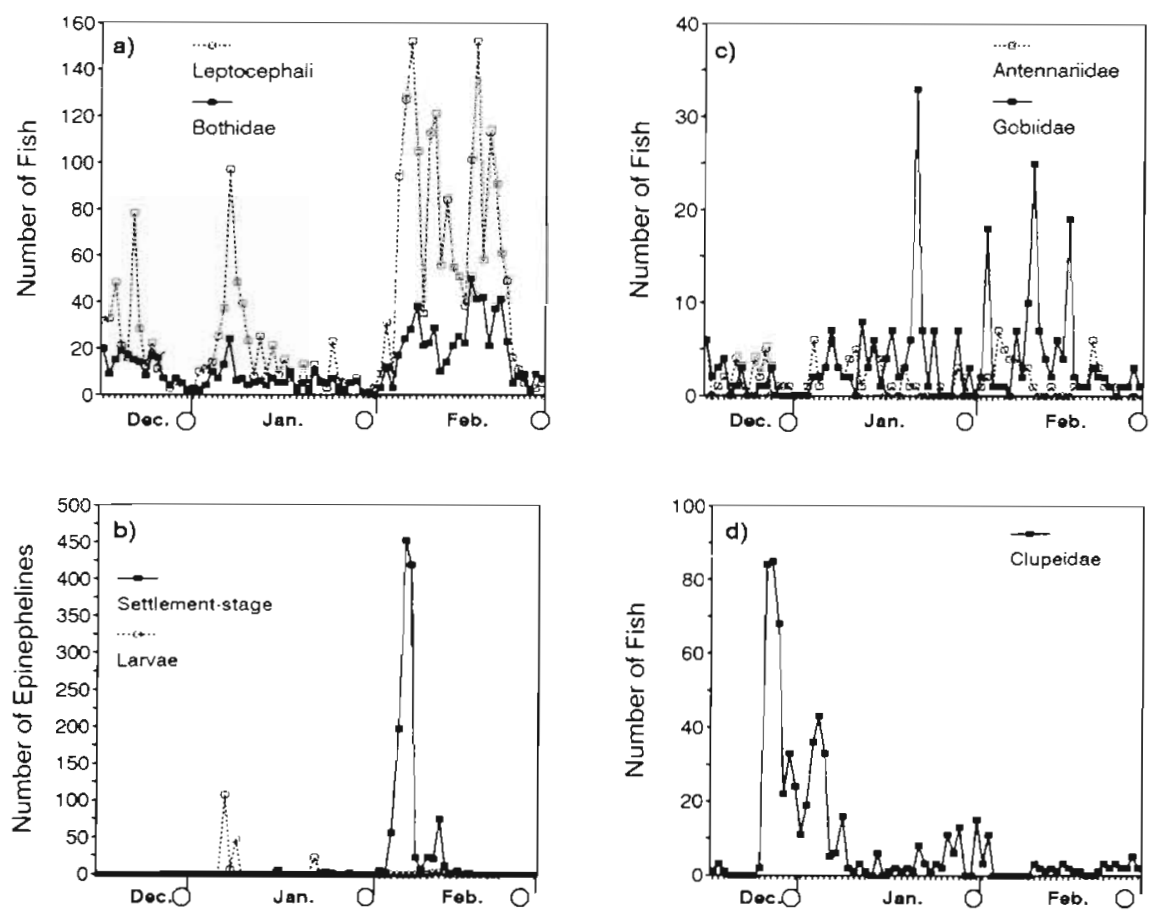

Fig. 7. Time-series of catches of fishes in all channel nets during the study period. $O$ : full moon nights. (a) Leptocephali and Bothidae. (b) Settlement-stage Epinephelus striatus and Epinepheline larvae. (c) Antennariidae and Gobidae. (d) Clupeidae

abundant on nights with high lunar illumination values and relatively few hours of dark flood tide.

Similar analysis of wind and current data indicates that onshore transport of most taxa relied heavily on cross-shelf winds and currents. Significantly higher proportions of the total catch of almost all taxa occurred on nights when the onshore component of winds ranged from 3 to $6 \mathrm{~m} \mathrm{~s}^{-1}$ ( $G$-test, Fig. 9a), and when currents at $10 \mathrm{~m}$ were moving across the shelf (Fig. 9b). The Gobiidae were the only fishes taken in larger numbers during periods of offshore winds, and the Clupeidae were taken in larger numbers during periods of offshore currents.

Table 2. Comparison of the total number of fish in each abundant taxon ( $>100$ specimens) that were collected in nighttime surface and subsurface samples. The surface nets fished the 0 to $1 \mathrm{~m}$ layer, while subsurface nets were suspended 2 to $4 \mathrm{~m}$ deep. To discern statistical differences between depth layers, paired t-tests were conducted using data standardized for the different net sizes and the slightly higher flow rate of the surface. S: Surface nets; SS: subsurface nets; ns: not significant

\begin{tabular}{|c|c|c|c|c|}
\hline Taxon & $\begin{array}{c}\text { No. of } \\
\text { specimens }\end{array}$ & $\begin{array}{c}\% \text { in } \\
\text { surface } \\
\text { nets }\end{array}$ & $\begin{array}{l}\text { Primary } \\
\text { depth } \\
\text { stratum }\end{array}$ & $p$-value \\
\hline Leptocephali & 2552 & 79.0 & S & 0.000 \\
\hline Serranidae & 1517 & 85.4 & S & 0.001 \\
\hline Bothidae & 926 & 68.3 & $\mathrm{~S}$ & 0.000 \\
\hline Clupeidae & 625 & 6.9 & SS & 0.001 \\
\hline Tetraodontidae & 444 & 81.1 & $\mathrm{~S}$ & 0.000 \\
\hline Acanthuridae & 377 & 37.4 & - & ns \\
\hline Blennioidei & 377 & 55.0 & S & 0.024 \\
\hline Gobiesocidae & 320 & 26.5 & - & $\mathrm{ns}$ \\
\hline Ophidiidae & 298 & 22.5 & SS & 0.019 \\
\hline Gobiidae & 270 & 59.6 & $\mathrm{~S}$ & 0.000 \\
\hline Balistidae & 258 & 73.3 & $\mathrm{~S}$ & 0.000 \\
\hline Apogonidae & 242 & 33.3 & - & ns \\
\hline Labridae & 227 & 41.9 & -- & ns \\
\hline Antennariidae & 135 & 50.4 & $\mathrm{~S}$ & 0.001 \\
\hline
\end{tabular}



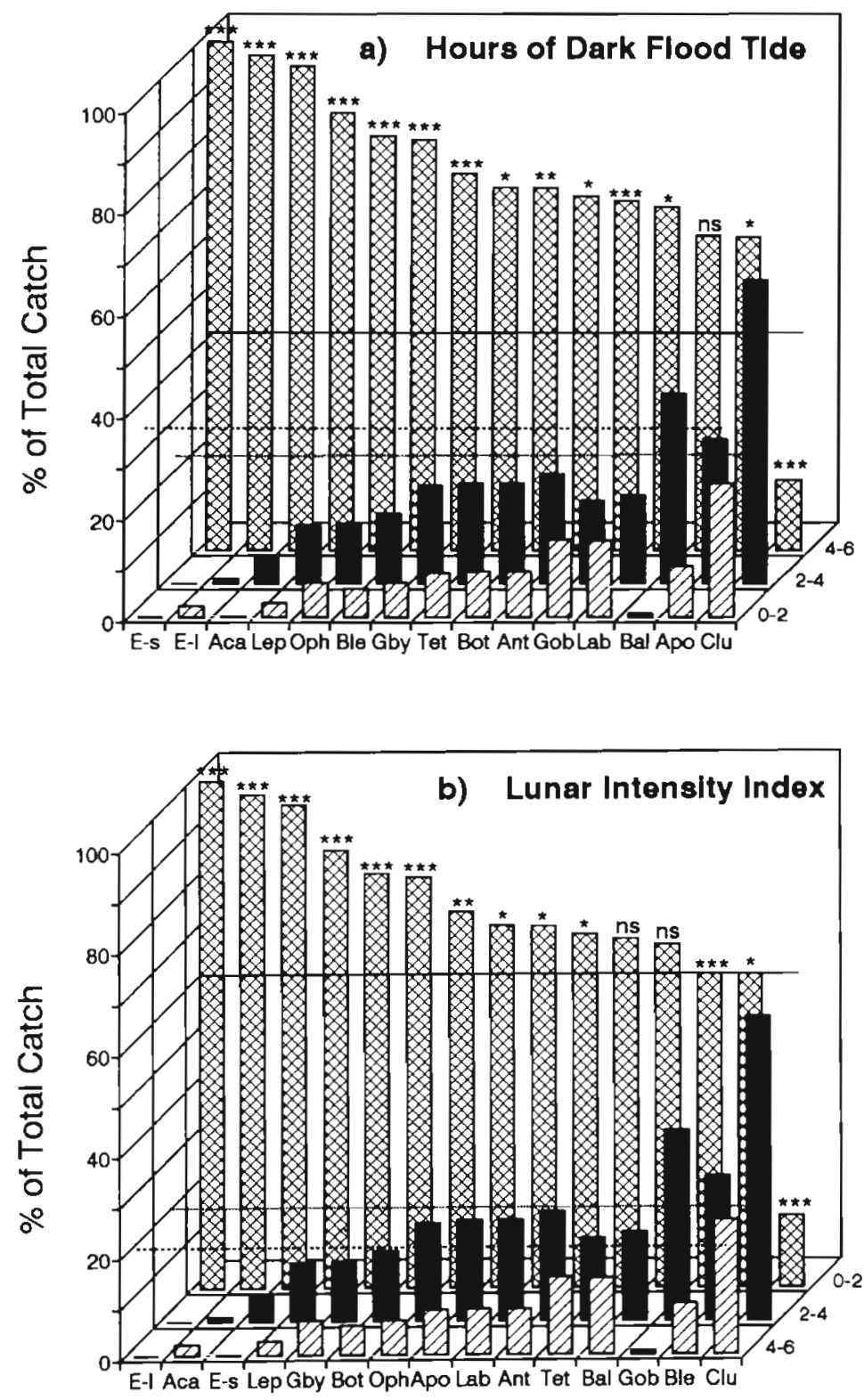

Fig. 8. Proportion of total catch of abundant taxa collected during the study period on nights with different amounts of flood tides occurring under dark (moonless) conditions, and with different lunar intensity levels during flood tides. Horizontal lines indicate the proportion of nights that met each category of the environmental variable. $\cdots p<0.001$; $\cdots p<0.01 ; " p<0.1$. Aca: Acanthuridae; Ant: Antennariidae; Apo: Apogonidae; Bal: Balistidae; Ble: Blennioidei; Bot: Bothidae; Clu: Clupeidae; E-1: Epinepheline larvae; E-s: settlement-stage Epinephelus striatus: Gob: Gobiesocidae; Gby: Gobiidae; Lab: Labridae; Lep: Leptocephali; Oph: Ophidiidae; Tet: Tetraodontidae

\section{DISCUSSION}

The study of mechanisms involved in structuring fish communities in coral reef environments has focused on the supply of new recruits to reefs and on interactions among species following settlement. In previous studies, recruitment was examined by frequent census of newly settled fishes on natural or artificial reefs (e.g. Shulman et al. 1983, Shulman 1985, Doherty 1987 Schroeder 1987, Robertson et al. 1988), or by back-calculating settlement dates from otoliths of juvenile fishes (Victor 1983 $1986 \mathrm{~b})$. Although the actual mechanisms driving recruitment of pelagic settlement-stage fishes were not addressed, it was strongly suspected that physical processes could affect not only the temporal and spatial patterns of recruitment, but subsequent fish community structure as well.

In this study, we present a long-term timeseries of marine tropical fishes captured while moving from the pelagic environment to their benthic nursery habitat. Lee Stocking Island, on the edge of Exuma Sound, is an ideal site for directly examining transport of fishes from the pelagic realm to the shallow nursery habitat. This region provides very close proximity between the 2 habitats, without the extensive shelf area and complex hydrographic features found in many regions that would complicate observations and analysis of movement.

The use of large channel nets moored between islands on the edge of Exuma Sound proved to be an effective way of examining the onshore movement of fishes. Large numbers of many taxa, particularly anguilliform leptocephali, serranids and bothids were captured. The abundance of leptocephali was striking. A total of 2735 specimens were collected, comprising $26 \%$ of the total fish catch. Approximately 2500 of the specimens were anguilliform larvae (Drass 1992). The sheer numbers of eel larvae suggests that these highly cryptic animals may be a far more abundant component of reef and grass flat habitats than previously suspected, and may play major roles in structuring fish and invertebrate communities. The need for assessment of the ecological role of these fishes is obvious.

Onshore movement of almost all taxa occurred under a set of specific environmental conditions. The great majority of fishes moving through the channels at the edge of Exuma Sound were captured on nights when most of the flood tide occurred during the moonless part of the night (Fig. 8a, b). Cross-shelf movement was enhanced when winds and near-surface currents had onshore components of motion (Fig. 9a, b). 

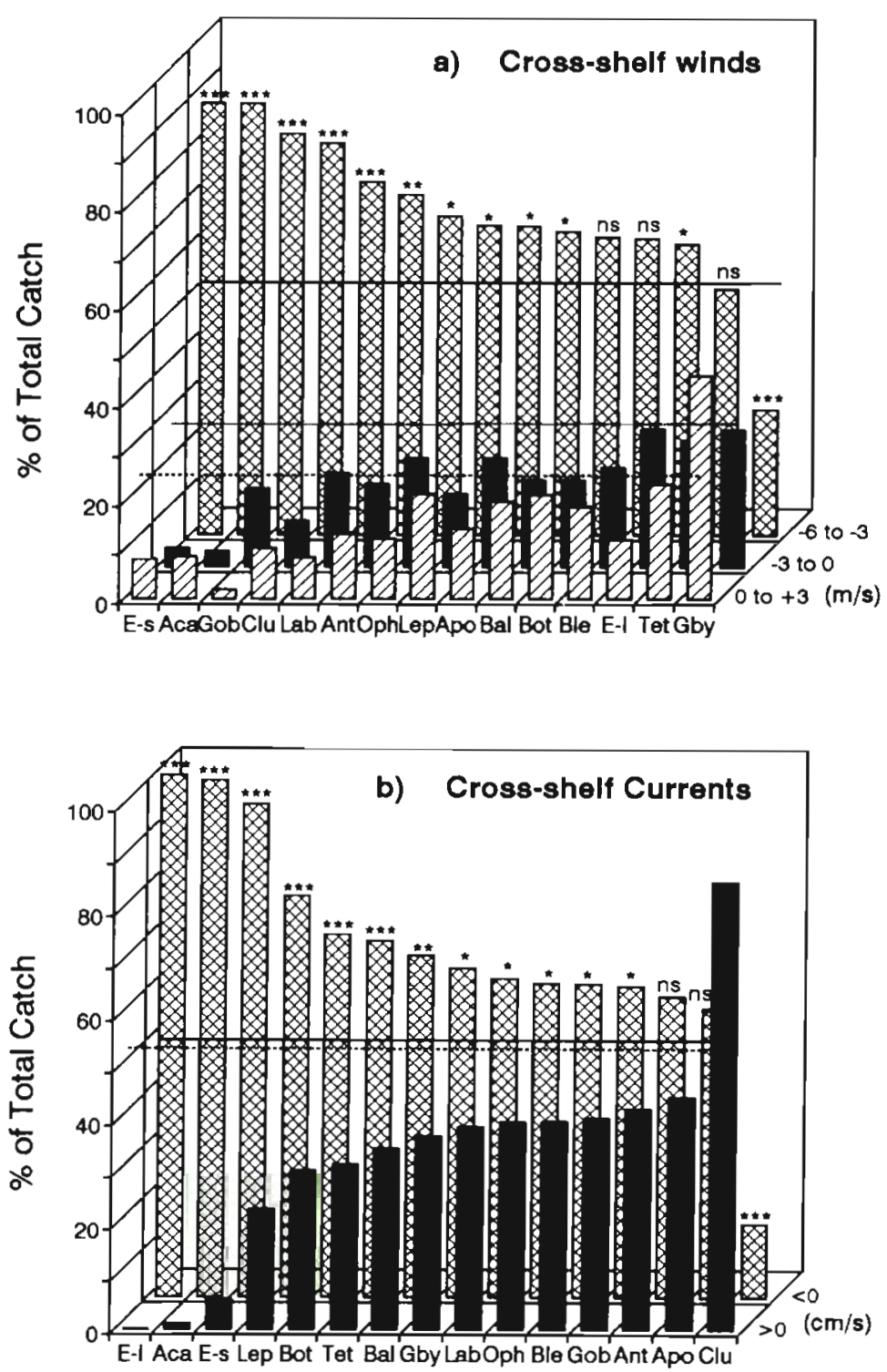

Fig. 9. Proportion of total catch of abundant taxa collected during the study period on nights with different cross-shelf winds and currents. Negative values indicate onshore winds and currents. Symbols and abbreviations as in Fig. 8

The collection of fishes primarily during dark nights can be interpreted in 2 ways: (1) the low capture rates during daytime and on moonlit nights simply reflect visual avoidance of the large channel nets; and (2) behavioral characteristics of most pelagic larval and settlement-stage fishes inhibit onshore movement during the day and on moonlit nights. One mechanism by which fishes can prevent such onshore transport is to vertically migrate below the surface layer during the day, and into the surface layer during dark times of the night.

We prefer the hypothesis that dark-night onshore transport is the result of fish behavior, rather than their net avoidance abilities. This pattern was consistent among all taxa but the Clupeidae, and included well-developed swimmers such as leptocephali and settlementstage Epinephelus striatus as well as small, relatively weak swimmers such as postmetamorphic Bothidae. These bothids, typically only about $10 \mathrm{~mm}$ in length, would not be expected to be as capable as the larger fishes in avoiding the large channel nets in current velocities exceeding $1 \mathrm{~m} \mathrm{~s}^{-1}$ (N. Smith unpubl. data).

Previous studies also support the hypothesis that onshore movement occurs on dark nights. Robertson et al. (1988) surveyed artificial reefs at dawn and dusk, and found that almost all new recruits of 18 taxa settled overnight. Victor $(1983,1984,1986 b)$ used otolith studies to demonstrate that settlement of the labrid Thalassoma bifasciatum occurred primarily during new moon periods. Similarly, French grunts Haemulon flavolineatum recruited during dark lunar periods (McFarland et al. 1985).

The avoidance of visual predators is presumably a major selective pressure for evolution of behavioral traits that concentrate recruitment during dark nights. Vertical migration in response to changing light levels is a likely mechanism that could enable fishes to restrict their recruitment to dark nights. By avoiding the surface layer during the daytime and on bright nights, larval and settlement-stage fishes would minimize predation from surface dwelling pelagic predators. This tactic would also keep them from being entrained into onshore surface currents that would lead them into the 'wall of mouths' of planktivorous fishes inhabiting the seaward edges of reefs (Hamner et al. 1988), and toward the abundant assemblage of visual predators that inhabit benthic settlement sites.

The inferred vertical migration in response to light levels sets the stage for recruitment, but the wind and current data indicates that actual onshore transport relies heavily on cross-shelf winds and currents. Significantly higher proportions of the total catch of almost all taxa occurred on nights when winds and currents had onshore components of motion (Fig. 9a, b). In addition, the densities of fishes collected during recruitment events at the times of the February storms (Fig. $6 \mathrm{c}$ to e) were far higher than during the low recruitment periods in late January (Fig. 6a, b). It thus appears likely that water in flood tides moving through 
the channels during calm periods came from over the narrow shelf, and contained relatively few fishes. During the periods of northeast winds under dark night conditions, however, cross-shelf flow brought Exuma Sound water containing higher densities of fishes toward the coast where they could be entrained into the flood tide flow.

The Clupeidae and Gobijdae were the only fishes that acted contrary to this pattern of onshore movement of dark nights during cross-shelf flow conditions. Clupeids were taken in higher numbers on bright moonlit nights, and when near-surface currents were moving offshore. Schools of these 20 to $40 \mathrm{~mm}$ long, highly mobile epipelagic fishes may utilize different portions of the pelagic and shallow water environments under different environmental conditions. Gobiids were taken most frequently when winds were blowing offshore. Catches included many 10 to $20 \mathrm{~mm}$ specimens that had the full coloration of benthic juveniles. These fishes may have settled prior to capture, and reentered the water column when offshore winds created significant turbulence on the shallow bank habitats.

The protracted recruitment periods of leptocephali, Bothidae and many other taxa presumably represent the results of extended spawning periods and/or long larval life spans. The extensive supply of larvae permits local recruitment to occur whenever appropriate lunar and oceanographic/meteorological conditions occur.

Conversely, local recruitment of species with greatly restricted spawning periods is far more vulnerable to episodic environmental events. Epinephelus striatus provided the most dramatic recruitment of this sort that was observed. Adults are typically widely dispersed along reef systems, and gather in large spawning aggregations during one or two full moon periods in the winter (Smith 1972, Colin et al. 1987, Carter 1988, Colin 1992). Spawning activity peaks in the $10 \mathrm{~min}$ prior to sunset, resulting in release of patches of eggs each evening for ca $1 \mathrm{wk}$. Locations of the aggregations persist for many years, and are often know by local fishermen, but the spawning site(s) along the west side of Exuma Sound have not yet been discovered.

Some Epinephelus striatus spawning apparently occurred around the full moon on 2 December, and a total of nine 20 to $25 \mathrm{~mm}$ specimens were collected on 11 to 16 January (Fig. 7b), during a new moon phase. A similar 35 to $45 \mathrm{~d}$ long pelagic larval phase was observed for E. striatus at LSI during the winters of 1988-1989 and 1989-1990 (P. L. Colin pers. comm.).

Spawning around the full moon on 30 December resulted in vivid demonstrations of the effects of winddriven currents on cross-shelf transport. A pulse of 5 to $8 \mathrm{~mm}$ larvae was washed through the channels on 7 to
9 January during a period of northerly winds and dark nights. The spawning aggregation was thus presumably located within an approximate 7 to $10 \mathrm{~d}$ drift north of LSI. Similar early larvae were captured during ichthyoplankton surveys seaward of LSI from 10-19 January, reaching a maximum size of $12 \mathrm{~mm}$ (Greenwood \& Shenker in press). After 19 January, larvae disappeared from the sampling transect.

Light and variable winds persisted until a strong storm front passed over Exuma Sound, beginning on 3 February. This front was characterized by northeasterly winds and cross-shelf flow (Fig. 3), and coincided precisely with a major pulse of recruitment of settlement-stage Epinephelus striatus and many other taxa. Cross-shelf flow a few days later drove a second, smaller pulse of grouper recruitment. Settlement for the species then ceased.

This short and intense recruitment episode, apparently driven by epidsodic weather events, illustrates the vulnerability of local populations of these fishes to unpredictable conditions. Sampling with 1 midwater net at Stn 3 (P. L. Colin pers. comm.) resulted in collection of only 7 and $15 \mathrm{E}$. striatus during the previous 2 winters. Weather data for these times are not available, but passage of strong storms during the time when grouper were presumably competent to settle was not noted in field records. The storms in February 1991 resulted in a major settlement pulse, and collection of 1302 E. striatus in the channel nets. This extreme interannual variability in local recruitment may thus be influenced by the fortuitous occurrence of storms that drive cross-shelf flow at the precise time that larvae become competent to settle.

The question remains about the fate of pelagic settlement-stage Epinephelus striatus if the storm events in February had not occurred. Unlike most other coral reef environments, the semi-enclosed Exuma Sound is almost completely surrounded by potential nursery habitats. It is possible that different weather patterns would result in transport of fishes to other locations on the periphery of the sound, resulting in a temporally and spatially patchy local recruitment pattern over the years.

Similar data showing very discrete pulses of recruitment of other taxa have been inferred from visual census, otolith and light trap data for a variety of other tropical taxa, including labrids, pomacentrids, and balistids (e.g. Victor 1983, 1986a, b, Doherty 1987, Robertson et al. 1988, Milicich et al. 1992). However, the role of meteorological and oceanographic conditions in transporting these pulses to the settlement sites have not been determined. In temperate waters, the role of wind-driven currents in affecting recruitment is becoming increasingly clear. Checkley et al. (1988) determined that spawning of Atlantic menhaden 
Brevoortia tyrannus along the western edge of the Gulf Stream off North Carolina (USA) was triggered by winter storm events which induced shoreward flow of larvae in the surface layer. Onshore movements of Atlantic mackerel Scomber scombrus in the Gulf of St. Lawrence was found to be associated with wind-driven advection of warm surface currents (Castonguay et al. 1992).

During the storm-driven recruitment pulses observed near LSI, the great majority of fishes of the most abundant taxa were found in the upper $1 \mathrm{~m}$ of the water column (Fig. $6 \mathrm{c}$ to e), despite turbulent conditions with wave heights of 1 to $2 \mathrm{~m}$. The dramatic utilization of this highly turbulent layer is intriguing. One hypothesis for this vertical pattern is that the surface layer is most rapidly influenced by wind, and should provide the fastest horizontal movement. It is tempting to visualize the very surface layer as a 'conveyor belt' upon which settlement-stage fishes can move toward their shallow nursery habitats.

The relationships between recruitment, lunar intensity and time of flood tides suggest mechanisms where recruitment can vary significantly over relatively short distances, despite the occurrence of favorable current conditions. If the time of flood tide varies along a series of islands or reef fronts, it is possible that recruitment could be high where flood tides occur during the dark, and lower in areas where a shift of even 1 to $2 \mathrm{~h}$ in the tides causes more of the flood to occur during moonlit hours. Such a mechanism (coupled with patchiness of the pelagic larvae, and broad scale variation in spawning effort and current patterns), could explain the coherence of recruitment over relatively small scales (1 to $50 \mathrm{~km}$ i Victor 1984, 1986a, Pitcher 1988), and marked variation in timing of recruitment over larger reef fronts (Doherty 1987, Doherty \& Williams 1988).

Acknowledgements. This research was supported by a grant from the National Undersea Research Program of the National Oceanic and Atmospheric Administration to the Caribbean Marine Research Center. We thank the large group of student volunteers who assisted in the arduous collection and initial processing of samples, and P. Pitts for his help in analyzing environmental data. J. Grover, J. Lin, B. Olla, R. Wicklund and several anonymous reviewers provided helpful comments on the manuscript. K. Clark provided graphic computer services using equipment funded by grant BIR 8951326 from the NSF Instrumentation and Laboratory Improvement Program.

\section{LITERATURE CITED}

Bannerot, S. P., Fox, W. W. Jr, Powers, J. E. (1987). Reproductive strategies and the management of snappers and groupers in the Gulf of Mexico and Caribbean. In: Polovina, J J., Ralston, S. (eds.) Tropical snappers and groupers: biology and fisheries management. Westview Press, Boulder, p. 561-603

Carter, H. J. (1988). Grouper mating ritual on a Caribbean reef. Underwat. Nat. 17: 8-11

Castonguay, M., Rose, G. A., Leggett, W. C. (1992). Onshore movements of Atlantic mackerel (Scomber scombrus) in the northern Gulf of St. Lawrence: associations with windforced advections of warmed surface waters. Can. J. Fish. Aquat. Sci. 49: 2232-2241

Checkley, D. M. Jr, Raman, S., Maillet, G. L., Mason, K. M. (1988). Winter storm effects on the spawning and larval drift of a pelagic fish. Nature 335: 346-347

Chlebowski, M. H. (1991). Species abundance and spatial distribution of larval surgeonfish (Acanthuridae) around Lee Stocking Island, Bahamas. M.Sc. thesis, Florida Institute of Technology, Melbourne

Colin, P. L. (1992). Reproduction of the Nassau grouper Epinephelus striatus (Pisces: Serranidae) and its relationship to environmental conditions. Environ. Biol. Fish. 34: $357-377$

Colin, P. L. Shapiro, D. Y., Weiler, D. (1987). Aspects of the reproduction of two groupers, Epinephelus guttatus and $E$. striatus, in the West Indies. Bull. mar. Sci. 40: $220-230$

Doherty, P. J. (1987). The replenishment of populations of coral reef fishes, recruitment surveys, and the problems of variability manifest on multiple scales. Bull. mar. Sci. 41; $411-422$

Doherty, P. J. (1991). Spatial and temporal patterns in recruitment. In: Sale, P. F. (ed.) The ecology of fishes on coral reefs. Academic Press, New York, p. 261-293

Doherty, P. J., Williams, D. M. (1988). The replenishment of coral reef fish populations. Oceanogr. mar. Biol. A. Rev. 26: $487-551$

Drass, D. M. (1992). Onshore movements and distribution of leptocephali (Osateichthyes: Elopomorpha) in the Bahamas. M.Sc. thesis, Florida Institute of Technology, Melbourne

Greenwood, C. B., Shenker, J. M. (in press). Distribution, abundance, growth and feeding habits of larval Epinephelus striatus and E. fulvus (Pisces: Serranidae) in Exuma Sound, Bahamas. Fish Bull. U.S.

Hamner, W. M., Jones, M. S., Carleton, J. H., Haur, I. R., Williams, D. M. (1988). Zooplankton, planktivorous fish, and water currents on a windward reef face: Great Barrier Reef, Australia. Bull. mar. Sci. 42: 459-479

Jones, G. P. (1991). Postrecruitment processes in the ecology of coral reef fish populations: a multifactorial perspective. In: Sale, P. F. (ed.) The ecology of fishes on coral reefs. Academic Press, New York, p. 294-330

Leis, J. M. (1991). The pelagic stage of reef fishes: the larval biology of coral reef fishes. In: Sale, P. F. (ed.) The ecology of fishes on coral reefs. Academic Press, New York, p. $183-230$

McFarland, W. N., Brothers, E. B., Ogden, J C., Shulman, M. J., Bermingham, E. L, Kotchian-Prentiss, N. M. (1985). Recruitment patterns in young French grunts, Haemulon flavolineatum (family Haemulidae) at St. Croix, U.S.V.I Fish. Bull. U.S. 83: 413-426

Milicich, M. J. (1988). The distribution and abundance of presettlement fish in the nearshore waters of Lizard Island. In: Choat, J. H. et al. (eds.) Proc. 6th int coral Reef Symp. 2: $785-790$

Milicich, M. J., Meekan, M. G., Doherty, P.J. (1992). Larval supply: a good predictor of recruitment of three species of reef fish (Pomacentridae). Mar Ecol. Prog. Ser. 86: 153-166 
Pitcher, C. R. (1988). Spatial variation in the temporal pattern of recruitment of a coral reef damselfish. In: Choat, $J . \mathrm{H}$. et al. (eds.) Proc. 6th int. coral Reef Symp. 2: 811-816

Robertson, D. R., Green, D. G., Victor, B. C. (1988). Temporal coupling of reproduction and recruitment of larvae of a Caribbean reef fish. Ecology 69: 370-381

Sale, P. F. (1990). Recruitment of marine species: Is the bandwagon rolling in the right direction? Trends Ecol. Evol. (TREE) 5: 25-27

Schroeder, R. E. (1987). Effects of patch reef size and isolation on coral reef fish recruitment. Bull. mar. Sci. 41: 441-451

Shulman, M. J., Ogden, J. C., Ebersole, J. P., McFarland, W. N., Miller, S. L., Wolf, N. G. (1983). Priority effects in the recruitment of juvenile coral reef fishes. Ecology 64 : $1508-1513$

Shulman, M. J. (1985). Recruitment of coral reef fishes: Effects of distribution of predators and shelter. Ecology 66 : $1056-1066$

Smith, C. L. (1972). A spawning aggregation of Nassau grouper, Epinephelus striatus (Bloch). Trans. Am. Fish. Soc. 101: 257-261

Sokal, R. R., Rohlf, F. J (1981). Biometry, 2nd edn. W. H. Freeman, San Francisco

This article was presented by $K$. Sherman, Narragansett, Rhode Island, USA
Thorrold, S. R., Milicich, M. J. (1990). Comparison of larval duration and pre- and post-settlement growth in two species of damselfish, Chromis atripectoralis and Pomacentrus coelestis (Pisces: Pomacentridae), from the Great Barrier Reef. Mar. Biol. 105: 375-384

Victor, B. C. (1982). Daily otolith increments and recruit-ment in two coral-reef wrasses, Thalassoma bifasciatum and Halichoeres bivittatus. Mar. Biol. 71. 203-208

Victor, B. C. (1983). Recruitment and population dynamics of a coral reef fish. Science 219: 419-420

Victor, B. C. (1984). Coral reef fish larvae: patch size estimation and mixing in the plankton. Limnol. Oceanogr. 29: $1116-1119$

Victor, B. C. (1986a). Delayed metamorphosis with reduced larval growth in a coral reef fish (Thalassoma bifasciatum). Can. J. Fish. Aquat. Sci. 43: 1208-1213

Victor, B. C. (1986b). Larval settlement and juvenile mortality in a recruitment-limited coral reef fish population. Ecol. Monogr. 56: 145-160

Victor, B. C. (1991). Settlement strategies and biogeography of reef fishes. In: Sale, P. F. (ed.) The ecology of fishes on coral reefs. Academic Press, New York, p. $231-260$

Manuscript first received: December 10, 1992

Revised version accepted: April 30, 1993 